Clim. Past Discuss., https://doi.org/10.5194/cp-2017-137

Manuscript under review for journal Clim. Past

Discussion started: 21 November 2017

(c) Author(s) 2017. CC BY 4.0 License.

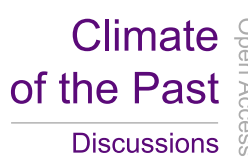

(c) (1)

\title{
Patterns of extreme weather associated with observed and proxy River Ammer flood records
}

Norel Rimbu ${ }^{1}$, Monica Ionita ${ }^{1,2}$, Markus Czymzik ${ }^{3,5}$, Achim Brauer ${ }^{4}$ and Gerrit Lohmann ${ }^{1,2}$

$5 \quad{ }^{1}$ Alfred Wegener Institute Helmholtz Centre for Polar and Marine Research, Bremerhaven, Germany

${ }^{2}$ MARUM - Center for Marine Environmental Sciences, University of Bremen, Bremen, Germany ${ }^{3}$ Lund

University, Department of Geology, Lund, Sweden

${ }^{4}$ GFZ German Research Centre for Geosciences, Climate Dynamics and Landscape Evolution, Potsdam, Germany

10 Leibniz Institute for Baltic Sea Research (IOW), Marine Geology, Rostock-Warnemünde,

Germany

Correspondence to: N. Rimbu (norel.rimbu@awi.de)

Alfred Wegener Institute Helmholtz Center for Polar and Marine Research

Bussestr. 24

27570, Bremerhaven

Germany 
Clim. Past Discuss., https://doi.org/10.5194/cp-2017-137

Manuscript under review for journal Clim. Past

Discussion started: 21 November 2017

(c) Author(s) 2017. CC BY 4.0 License.

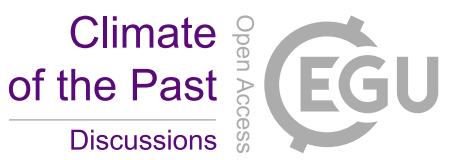

(c) (i)

\section{Abstract}

We investigate the relationship between the variability in the frequency of River Ammer floods (southern Germany) and temperature/precipitation extremes over Europe using observational River Ammer discharge data back to 1926 and the 5500-year-long flood layer record from varved Lake Ammersee sediments. We show that observed River Ammer flood frequency variability is not only related with local extreme precipitation, but also with large-scale temperature extreme anomalies. Less (more) extreme high temperatures over central and western (northeastern) Europe are recorded during periods of increased River Ammer flood frequency.

40 We argue that changing radiative forcing due to cloudiness anomaly patterns associated with River Ammer floods induce these extreme temperature anomalies. Consistent patterns are obtained using observed discharge and proxy flood layer frequency data. Furthermore, a higher frequency of observed River Ammer floods and flood layers is associated with enhanced blocking activity over northeastern Europe. A blocking high over this region increases the probability of wave breaking and associated heavy precipitation over western Europe. A similar blocking pattern is associated with periods of reduced solar activity. Consequently, solar modulated changes in blocking frequency over northeastern Europe could explain the connection between River Ammer floods and solar activity, as also identified in previous studies. We argue that multi-decadal to millennial flood frequency variations in the Mid- to Late Holocene flood

50 layer record from Lake Ammersee characterizes also the extreme temperatures in northeastern Europe. 


\section{Introduction}

Over the past decades Europe has experienced heavy floods with major socioeconomic consequences. One of these cases is the summer 2013 flood in Central Europe (Ionita et al., 2015), emphasizing the need for improved forecast methods of extreme climatic/hydrologic events and a better understanding of the underlying hydrometeorological climatic processes. In particular, understanding past changes of floods on short and long time- scales is crucial for anticipating the evolution of these events in response to climate change.

Much of the current climate debate focuses on global temperature fluctuations. Less debate is on regional changes in extreme climate events, particularly on extreme floods. One way to address this issue is to examine past floods using hydrological measurements. By employing historical documents and natural archives (including alluvial, marine, and lake sediments; tree rings; and cave formations) we can extend this knowledge back through the Holocene period or beyond (Swierczynski et al., 2017). Integrating instrumental and proxy records can provide valuable information about long-term flood trends, at very high precision.

The main driver of floods are hydrological extremes (e.g. Czymzik et al., 2013), usually associated with specific atmospheric circulation patterns like zonal westerly or meandering regimes (e.g. Zängl et al., 2007) or VB cyclone tracks (e.g. Swierczynski et al., 2012). However, such circulation regimes are related not only to local extreme precipitation and floods, but could also be associated with extreme weather phenomena in more distant regions.

The main goal of the current study is to identify extreme temperature and precipitation anomaly patterns associated with the variability in the frequency of River Ammer (southern Germany) floods. Therefore, we combine instrumental River Ammer discharge data back to 1926 with the seasonally resolved flood layer time-series from varved sediments of the downstream Lake Ammersee covering the last 5500 years. Detecting such features can improve the interpretation of flood layer records from Lake Ammersee sediments (Czymzik et al., 2010), in terms of extreme weather and climate variations. Previous studies connected varying stable oxygen isotope contents in central Greenland ice cores (Rimbu et al., 2016a) as well as tree ring variability from Scandinavia (Peng et al., 2016) with temperature extremes over Europe during instrumental and pre-instrumental period. 
This article is organized as follows. Data and methods are presented in Section 2. Results are presented in Section 3. The relationship between observed daily River Ammer floods and daily precipitation and extreme temperatures for the period AD 2015-1926 is discussed in Section 3.1. In Section 3.2, the seasonal patterns of precipitation and temperature extreme indices associated with observed River Ammer flood summers are presented. Similar analyses, but for flood layer years recorded in a varved Lake Ammersee sediments back to 1871 are presented in Section 3.3. Possible consequences of solar activity induced changes in blocking activity over northeastern Europe on River Ammer flood frequency is discussed in Section 3.4. Furthermore, Section 3.4 discusses millennial scale variability of flood layer frequency in Lake Ammersee sediments and their possible implications for extreme climates throughout the last 5500 years. A summary and the main conclusions are given in Section 4.

\section{Data and methods}

The main quantity analyzed here is the mean daily River Ammer runoff recorded at Gauge Weilheim (Bayerisches Landesamt für Umwelt, 2007) covering the period 1926 to 2015. River Ammer arises in the Bavarian Alps and flows northward to Lake Ammersee (Fig. 1a). Details about the River Ammer characteristics can be found in e.g. Ludwig et al. (2013) and Petrow and Merz (2009). Here we examine the observed daily discharge of River Ammer during summer (June, July, August), the main flood season in the Ammer region (Czymzik et al., 2010). We combine the discharge data with the 5500-year flood layer record from varved Lake Ammersee sediments, a proxy for River Ammer flood frequency in spring and summer (Czymzik et al., 2010). A daily River Ammer discharge of $>125 \mathrm{~m}^{3} / \mathrm{s}$ is defined as a flood day, since above that threshold the deposition of a flood layer in Lake Ammersee sediments becomes very likely (Czymzik et al., 2010). The main goal of this paper is to relate River Ammer flood frequency variability from the discharge and sedimentological records to extreme climate anomaly patterns. Daily maximum temperature (TX) and daily precipitation amount (RR) during summer for the period 1950-2015 were extracted from gridded E-OBS data set, version 14 (e.g. Haylock et al., 2008). Daily total cloud cover over the period 1926-2014 were extracted from the 20th century reanalysis data sets (20CR), version 2 (Compo et al., 2011). Heavy precipitation days (r10mm) index defined as the number of days per summer with precipitation amount higher than $10 \mathrm{~mm}$ (e.g. Karl et al., 1999) were analyzed in connection with the frequency of Ammer flood days during summer. As a measure of extreme temperature we have used the percentile threshold 
Clim. Past Discuss., https://doi.org/10.5194/cp-2017-137

Manuscript under review for journal Clim. Past

Discussion started: 21 November 2017

(c) Author(s) 2017. CC BY 4.0 License.

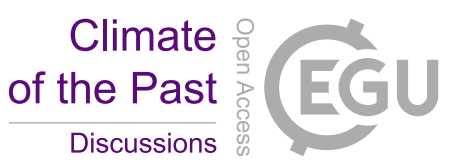

index TX90p (warm days), defined as number of days per summer with maximum daily temperature (TX) above the $90^{\text {th }}$ percentile of the TX distribution in the 1961-90 baseline period (e.g. Karl et al., 1999). These precipitation and temperature indices, for the period 1950-2015, are calculated based on daily precipitation and daily extreme temperatures from the gridded EOBS data set. The extreme temperature anomaly patterns associated with flood layers during the period 1901 to1999 were extracted from the station-based ECA\&D data set (http://www.ecad.eu). Only stations with more than $30 \%$ defined values were selected for composite analyses.

Summer daily geopotential height (Z500) data for the period 1871-2014 was downloaded from the 20CR data base, version 2 (Compo et al., 2011). The two-dimensional blocking index defined by Scherrer et al. (2006) over the period 1871-1999 was calculated using daily Z500 data and used in a composite analysis to derive the blocking anomaly pattern associated with River Ammer floods in the discharge and flood layer records. Singular Spectrum Analysis (SSA) (Ghil et al., 2002) was used to identify quasi-periodic components in the Lake Ammersee flood layer record.

\section{Results}

The River Ammer discharge during summer (Fig. 1b) shows no significant linear trend from 1926 to 2015 . Mean summer discharge is $18 \mathrm{~m}^{3} / \mathrm{s}$ while the standard deviation is $15 \mathrm{~m}^{3} / \mathrm{s}$. The frequency of flood days $>125 \mathrm{~m}^{3} / \mathrm{s}$ discharge shows pronounced decadal variations within the period 1926-2015.

\subsection{Atmospheric circulation patterns associated with daily River Ammer floods during} summer

A correlation analysis reveals that River Ammer discharge between 1926 and 2015 is correlated at maximum with previous day local precipitation (not shown). Therefore, we investigate the atmospheric circulation pattern one-day prior to a River Ammer flood days $>125 \mathrm{~m}^{3} / \mathrm{s}$ discharge (day -1). The Z500 composite map (Fig. 2) shows a pronounced trough over western and central Europe, similar to that associated with River Ammer flood days around the year (Rimbu et al., 2016b). This is due to the fact that the majority of flood days occur during summer (Czymzik et al., 2010). The Z500 anomaly pattern (Fig. 2, shaded) contains elements of two synoptic patterns associated with debris flows in the Swiss Alps as described by Toreti et al. (2013) (their Fig. 2) 
Clim. Past Discuss., https://doi.org/10.5194/cp-2017-137

Manuscript under review for journal Clim. Past

Discussion started: 21 November 2017

(c) Author(s) 2017. CC BY 4.0 License.

and is consistent with synoptic scale patterns that leads to clustering of extreme precipitation events in Switzerland (Barton et al., 2016). The corresponding precipitation anomaly maps (Fig. 3a) depicts positive anomalies in the Alpine region with a strong maximum in the Ammer region. Negative precipitation anomalies, but bellow on 95\% significance level, are recorded over parts of western and north-eastern Europe. The composite map of maximum daily temperature (TX) (Fig. 3b) yields strong negative anomalies over central and south-western Europe as well as positive anomalies over north-eastern Europe.

Cloudiness is an important forcing factor of extreme temperatures and dry/wet periods during summer (e.g. Andrade et al., 2012; Ionita et al., 2015). The cloudiness anomaly pattern associated with River Ammer flood days (Fig. 4) shows positive anomalies in the Alpine region, consistent with positive precipitation anomalies in the region (Fig 3a). It shows also negative cloudiness anomalies over northeastern and northwestern Europe, consistent with negative precipitation anomalies in these regions during flood days. The cloudiness anomaly pattern (Fig. 4) is also in agreement with the extreme temperature pattern (Fig. 3b). Enhanced (reduced) cloudiness is associated with less (more) local temperature extremes during summer (Andrade et al., 2012).

\subsection{Extreme climate anomaly patterns associated with observed summer River Ammer floods}

The frequency of River Ammer flood days during summer (Fig. 5a) shows pronounced decadal variations. Flood days are relatively frequent during the periods 1950-1980 and 2000-2015, but less frequent from 1980 to 2000. Similar variations are obtained for River Ammer floods throughout the complete year (Rimbu et al., 2016b). Again, this is due to the fact that major River Ammer floods occur nearly exclusively during late spring and summer (Czymzik et al., 2010). During periods with more flood days, positive anomalies of heavy rain days frequency (r10mm index) are recorded in central and southern Europe while negative anomalies prevail over northeastern Europe (Fig 5b). Extreme high temperature (TX90p) anomalies occur more frequently over northeastern Europe during periods with more River Ammer flood days during summer (Fig. 5c). Both extreme precipitation and temperature pattern (Figs. 5b and c) are consistent with cloudiness anomaly patterns (Fig. 4).

An important forcing factor which favors extreme precipitation in the Alpine realm is atmospheric blocking over northeastern Europe (Barton et al., 2016). Therefore, we investigate 
Clim. Past Discuss., https://doi.org/10.5194/cp-2017-137

Manuscript under review for journal Clim. Past

Discussion started: 21 November 2017

(c) Author(s) 2017. CC BY 4.0 License.

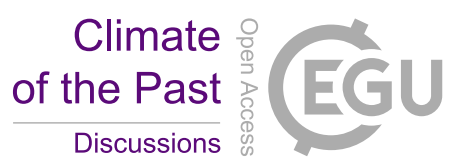

the relationship between River Ammer flood variability and blocking activity over Europe during summer. Consistent with the study by Barton et al (2016), positive blocking frequency anomalies are recorded in this region during summers with increased flood frequency (Fig. 6).

\subsection{Extreme climate anomaly patterns associated with flood layer variability}

Flood layer frequency in varved Lake Ammersee sediments during the 129-year period 18711999 (Fig. 7a) shows strong decadal variations. Flood layers are more frequent from 1950 to 1980, relative to 1981-1999, similar to the daily summer flood frequency in the shorter River Ammer discharge record (Section 3.2) (Fig. 5a). The blocking frequency anomaly pattern associated with flood layers shows positive anomalies over northeastern Europe (Fig. 7b), in agreement with the blocking pattern deduced from the River Ammer discharge record (Fig. 6).

The composite map of station-based TX90p anomalies shows predominant negative anomalies in the Alpine region and positive anomalies north of the Black Sea and south west of the Iberian Peninsula (Fig. 8). This TX90p pattern derived from flood layer data corresponds well to that obtained from the River Ammer discharge record (Fig. 5c) and is physically consistent with the corresponding cloudiness pattern (not shown) favoring strong (weak) radiative forcing over the region dominated by positive (negative) cloudiness anomalies.

\subsection{Possible relationship between flood frequency and solar forcing}

Previous studies (Wirth et al., 2013; Glur et al., 2015; Czymzik et al., 2016) have identified connections between solar activity changes and flood variability in the Alpine realm and, in particular, the Ammer region. A higher frequency of floods in the Alpine region is associated with reduced solar activity as well as with colder conditions.

To test these hypotheses, we investigate the role of atmospheric blocking within this relationship and compared an index of solar activity, i.e. the open solar flux (Lockwood et al., 2009), and summer blocking during the period 1871 to 2010. The blocking pattern associated with high solar irradiance (not shown) is relatively noisy. However, there is a clear increase in blocking frequency over northeastern Europe during summers with reduced solar activity (Fig. 9). The blocking pattern resembles that associated with increased River Ammer floods derived from the discharge (Fig. 6) and flood layer records (Fig. 7b). This is expected because River Ammer flood frequency and solar activity are out-of-phase throughout the last 5500 years (Czymzik et al., 
Clim. Past Discuss., https://doi.org/10.5194/cp-2017-137

Manuscript under review for journal Clim. Past

Discussion started: 21 November 2017

(c) Author(s) 2017. CC BY 4.0 License.

2016). In addition, at synoptic time scales, persistent blocking events over eastern and northeastern Europe were associated with extreme precipitation events in Alpine region (Barton et al., 2016).

The time series of flood layer frequency back to $3560 \mathrm{yr}$ BC in a 10-yr non-overlapping moving window (Fig. 10a), shows pronounced centennial to millennial scale variations. 10-yr windows with more than 6 flood layers occur frequently around 1500-500 BC, 500-1000 AC and 15001800 AC. Window with no floods or less than 5 flood years are recorded with high frequency during 500-0 BC (Fig. 10a).

At multidecadal to centennial time scales the power spectrum of flood layer time series show enhanced variability at $\sim 80 \mathrm{yr}$ and $\sim 210 \mathrm{yr}$ (not shown). The time series of the frequency of flood layers in 10-yr non-overlapping windows (Fig. 10a) further shows strong millennial variations. The dominant quasiperiodic component, as identified with SSA of this time series, has a time scale of $\sim 2500 \mathrm{yr}$ (Fig. 10b). It captures the low frequency of flood layers around 0 and 32500 $\mathrm{yr} \mathrm{BC}$ as well as high flood layer frequency around $1500 \mathrm{yr} \mathrm{BC}$ and during the last millennium with a maximum during LIA. SSA reveals also a strong quasi-periodic component at $\sim 900$ years (Fig. 10c). A SSA of a total solar irradiance reconstruction (Steinhilber et al., 2009) reveals similar oscillations (not shown). Solar irradiance and flood layer frequency oscillations are outof-phase for the $\sim 2500 \mathrm{yr}$ and $\sim 900$ years cycles.

\section{Discussion}

A major issue of current debate in climate change impact science is the effect of climate variability on the spatial-temporal distribution of extreme meteorological and hydrological events and their synchrony at regional, continental and global scales. In this study, we show that summer flood variability of the River Ammer (southern Germany) deduced from instrumental discharge and flood layer proxy time series is related not only to local extreme precipitation, but also to synoptic-scale precipitation and temperature extremes. Such wider spatial relationships can be explained by the susceptibility in River Ammer floods to changes large-scale atmospheric circulation (Rimbu et al., 2016b).

Previous studies showed that observed all year daily River Ammer floods (discharge $>125 \mathrm{~m}^{3} / \mathrm{s}$ ) are associated with a pronounced trough over western Europe intercalated between two ridges south of Greenland and north of the Caspian Sea (Rimbu et al., 2016b). Meridional moisture transport, mainly from the North Atlantic towards central Europe, along the frontal zones of 
these air-pressure fields increases flood risk in the Ammer region. The summer only flood pattern presented in this study is similar to that of Rimbu et al. (2016b) because the majority of River Ammer floods occur during late spring and summer (Czymzik et al., 2010).

A high frequency of daily River Ammer floods during summer (discharge $>125 \mathrm{~m}^{3} / \mathrm{s}$ ) is associated with increased blocking frequency over northeastern Europe. A similar blocking pattern is connected with the occurrence of flood layers during the period 1851-1999. Previous studies (e.g. Barton et al., 2016) emphasize the importance of downstream blocking anticyclones in producing extreme precipitation and floods in the Alpine region. Such blocking anticyclones assist wave breaking over western Europe and play a major role in determining the recurrent occurrence of these phenomena causing heavy precipitation at the Alpine region. In this study, we show that these anticyclones play not only a dominant role in generating extreme precipitation events and floods in the Ammer region, but also in generating extreme temperature events in northeastern Europe. Such blocks are associated with clear sky conditions in northeastern Europe as well as with enhanced advection of warm air form the southeast. The combination of radiative and advective forcing leads to extreme temperatures in the region, as shown by the extreme climate anomalies associated with observed and proxy River Ammer floods.

Analysis of Holocene flood reconstructions in the European Alps (Wirth et al., 2013) reveals a rich spectrum of periodicities at multidecadal (87yr), centennial (104, 150, 208, 350, 500 and $710 \mathrm{yr}$ ) and millennial (900-1200 and 2500-3000yr) time scales. Similar periodicities characterize solar activity reconstructions (e.g. Stuiver and Braziunas, 1989). It was shown that flood frequency in the Alpine region was higher during cool periods in the Alpine region, coinciding with lows in solar activity (Wirth et al., 2013). Our SSA analysis of the River Ammer flood layer record reveals two millennial scale cycles at $\sim 2500$ and $\sim 900$ years. These cycles, which are identified in various Holocene records (e.g. Rimbu et al., 2004), characterize also solar activity and are referred to as the Hallstatt and Eddy cycle, respectively and could have an astronomical origin (Scafetta et al., 2016). The enhanced blocking activity during low solar activity over eastern Europe, which play an important role in increasing the wave breaking activity and extreme precipitation in the Alpine region (Barton et al., 2016), could, therefore, be mechanistically associated with lower solar activity. One modeled Sun-climate connection is the so-called solar top-down mechanism (Haigh, 1996; Gray et al., 2010; Ineson et al., 2011). Thereby, during periods of reduced solar activity, comparably large reductions in solar UV 
emissions are expected to induce reduced meridional pressure gradients favoring atmospheric blocking and meridional airflow, consistent with our results (e.g. Haigh, 1996; Ineson et al., 2011). Therefore, this mechanism might have also caused the detected changes in flood frequency in the Ammer region. However, while the model results suggest that the top-down mechanism is active only during winter and early spring (Czymzik et al., 2016), River Ammer floods occur during late spring and summer. This inconsistency can possibly be reconciled by cryospheric effects like ice cover in the Barents Sea and snow in Siberia, transferring the potentially solar induced winter climate into summer (Ogi et al., 2003). Other effects of changes in total solar irradiance and galactic cosmic rays on River Ammer flood occurrences cannot be ruled out at this stage.

\section{Concluding Remarks}

The flood layers in varved Lake Ammersee sediments reflect not only the local extreme precipitation variability, but also extreme temperature and precipitation variations in more distal regions. We show that enhanced blocking activity in northeastern Europe in associated with more frequent River Ammer floods as well more frequent flood layers in downstream Lake Ammersee sediment records. Persistent blocking anticyclones over northeastern Europe increases the probability of wave breaking and associated heavy precipitation and floods in the Alpine region, a mechanism proposed to explain clustering of heavy precipitation in Switzerland (Barton et al., 2016). Furthermore, enhanced blocking activity over northeastern Europe during summer is associated also with increased frequency of extreme high temperature in the region through radiative and advective forcing. Statistical analysis reveals a possible modulation of blocking activity over northeastern Europe by solar activity changes explaining the out-of-phase relationship between River Ammer flood frequency and solar activity as described in previous studies (e.g. Czymzik et al. 2016). The solar forcing could modulate summer blocking activity over northeastern Europe through the solar top-down mechanism (Haigh, 1996; Ineson et al. 2011) and winter-summer feedback mechanisms (Ogi et al., 2003).

River Ammer flood records can contain relevant information about low frequency extreme climatic indices over Europe during mid-to late Holocene period. Our analysis reveals persistent multidecadal to millennial scale cycles in flood frequency variability. Analysis of different proxy data as well as model experiments should be performed to assess the robustness of these cycles in extreme precipitation and temperature indices over Europe. This would have important 
Clim. Past Discuss., https://doi.org/10.5194/cp-2017-137

Manuscript under review for journal Clim. Past

Discussion started: 21 November 2017

(c) Author(s) 2017. CC BY 4.0 License.

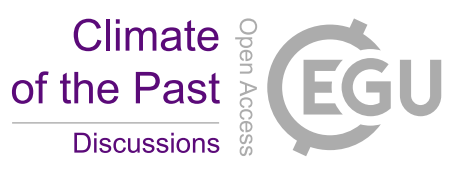

310 implications for prediction of extreme climate variability over Europe at multidecadal to millennial time scales. 
Clim. Past Discuss., https://doi.org/10.5194/cp-2017-137

Manuscript under review for journal Clim. Past

Discussion started: 21 November 2017

(c) Author(s) 2017. CC BY 4.0 License.

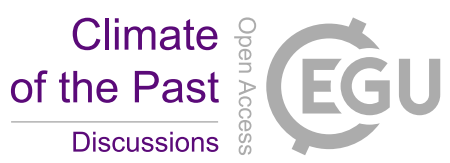

(c) (1)

Acknowledgements.

This study is promoted by Helmholtz funding through the Polar Regions and Coasts in the 335 Changing Earth System (PACES) program of the AWI and the Geosystem: The Changing Earth program of the GFZ. Funding by the Helmholtz Climate Initiative REKLIM and the Excellence Cluster Marum (OC3 "The Ocean in the Earth System" high- and low-latitude atmosphere-ocean interactions) is gratefully acknowledged. This study has used infrastructure of the Terrestrial Environmental Observatories (TERENO) of the Helmholtz Association. We acknowledge the EOBS dataset from the EU-FP6 project ENSEMBLES (http://ensembles-eu.metoffice.com) and the data providers in the ECA\&D project (http://www.ecad.eu). MC was funded by a German Science Foundation postdoc grant (DFG grant CZ 227/1-1). 
Andrade, C., Leite, M., and Santos, J. A.:Temperature extremes in Europe: overview of their driving atmospheric patterns, Nat. Hazards Earth Syst. Sci., 12, 671-1691, 239, doi:10.5194/nhess-12-1671-2012, 2012.

Barton, Y., P. Giannakaki, H. von Waldow, C. Chevalier, S. Pfahl, and O. Martius: Clustering of 347-369, https://doi.org/10.1175/MWR-D-15-0205.1, 2016.

Bayerisches Landesamt fur Umwelt: Daily River Ammer runoff data from 1926 to 2006, Munich, Germany, 2007.

Compo, G. P., Whitaker, J. S., Sardeshmukh, P.D., Matsui, N., Allan, R.J., Yin, X., Gleason, B.E., Vose, R.S., Rutledge, G., Bessemoulin, P., Brönnimann, S., Brunet, M., Crouthamel, R., Grant, A.N., Groisman, P. Y., Jones, P. D., Kruk, M. C., Kruger, A. C., Marshall, G. J., Maugeri, M., Mok, H. Y., Nordli, Ø., Ross, T. F., Trigo, R. M., Wang, X. L., Woodru , S. D., and Worley, S. J.: The Twentieth Century Reanalysis Project, Q. J. Roy. Meteor. Soc., 137, 1-28, doi:10.1002/qj.776, 2011. 248, 2011.

Czymzik, M., Dulski, P., Plessen, B., von Grafenstein, U., Naumann, R., and Brauer, A.: A 450 year record of spring-summer flood layers in annually laminated sediments from Lake Ammersee (southern Germany), Water Resour. Res., 46, W11528, doi:10.1029/2009WR008360, (2010).

Czymzik, M., Brauer, A., Dulski, P., Plessen, B., von Grafenstein, U., Naumann, R., and

Scheffler, R.: Orbital and solar forcing of shifts in Mid- to Late Holocene flood intensity from varved sediments of pre-alpine Lake Ammersee (southern Germany), Quaternary Sci. Rev., 61, 96-110, 2013. 256, 2013.

Czymzik, M., Muscheler. R., and Brauer, A.: Solar modulation of flood frequency in central Europe during spring and summer on interannual to multi-centenial time scales, Clim. Past, 12, 799-805, 2016.

Ghil, M., Allen,M.R., Dettinger, M.D., Ide, K., Kondrashov, D., Robertson, A.W., Saunders, A., Tian, Y., Vardi, F., and Yiou, P.: Advanced Spectral Methods for Climatic Time-Series, Rev. Geophy., 40, 2002. 
Glur, L., Stefanie, B. W., Buntgen, U., Gilli, A., Haug, G. H., Schar, C., Beer, J., and Anselmetti, 390 F. S.: Frequent floods in the European Alps coincide with cooler periods of the past 2500 years, Scientific Reports, 3, 2770, doi:10.1038/srep02770, 2013.

Gray, L. J., Beer, J., Geller, M., Haigh, J. D., Lockwood, M., Matthes, K., Cubasch, U., Fleitmann, D., Harrison, G., Hood, L., Luterbacher, J., Meehl, G. A., Shindell, D., van Geel, B., and White, W.: Solar influences on climate, Rev. Geophys., 48, RG4001, doi:10.1029/2009RG000282, 2010.

Haigh, J. D.: The impact of solar variability on climate, Science, 272, 981-984, 1996.

Haylock, M.R., Hofstra, N., Klein Tank, A.M.G., Klok, E.J., Jones, P.D., and New., M.: A European daily high-resolution gridded dataset of surface temperature and precipitation. $\mathrm{J}$. Geophys. Res (Atmospheres), 113, D20119, doi:10.1029/2008JD10201, 2008. D.: Solar forcing of winter cli- mate variability in the Northern Hemisphere, Nat. Geosci., 4, 753-757, 2011.

Ionita, M., Dima, M., Lohmann, G., Scholz, P., and Rimbu, N.: Predicting the June 2013 European Flooding based on Precipitation, Soil Moisture and Sea Level Pressure, J. Hydrometeorology, 16, 598-614., doi: http://dx.doi.org/10.1175/JHM-D-14-0156.1, 2014.

Ionita, M., C. Boroneant, S. Chelcea: Seasonal modes of dryness and wetness variability over Europe and their connections with large scale atmospheric circulation and global sea surface temperature. Climate Dynamics(2015), 45:2803, doi: 10.1007/s00382-015-2508-2, 2015.

Lockwood, M.A., Rouillard, P. and Finch, D.: The rise and fall of open solar flux during the current grand solar maximum, Astrophys.J., 700,937-944, 2009.

Ludwig, R., Tascher, S., and Mauser, W..: Modelling floods in the Ammer catchment: limitations and challenges with a coupled meteo-hydrological model approach, Hydrol. Earth Syst. Sci., 7, 833-847, 2013. 
Clim. Past Discuss., https://doi.org/10.5194/cp-2017-137

Manuscript under review for journal Clim. Past

Discussion started: 21 November 2017

(c) Author(s) 2017. CC BY 4.0 License.

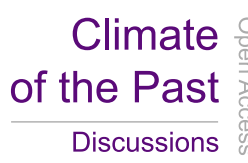

Ogi, M., Tachibana, Y., and Yamazaki, K.: Impact of the win- tertime North Atlantic Oscillation 415 (NAO) on the summer- time atmospheric circulation, Geophys. Res. Lett., 30, 1704, doi:10.1029/2003GL017280, 2003.

Peng, Z., Ionita, M., Lohmann, G., Chen, D., and Linderholm, HW.:Can tree-ring density datareflect summer temperature extremes and associated circulation patterns over Fennoscandia?, Clim. Dyn. doi: 10.1007/s00382-016-3452-5,2016.

420 Petrow, T., and Merz, B.: Trends in flood magnitude frequency and seasonality in Germany in the period 1951-2002, J. Hydrol., 371, 129-141, doi:10.1016/j.hydrol.2009.03.024, 2009.

Rimbu, N., Lohmann, G., Lorenz, SJ., Kim, JH, Schneider RR. (2004): Holocene climate variability as derived from alkenone sea surface temperature and coupled ocean-atmosphere model experiments, Clim. Dyn., 23, 215-227.

Rimbu, N., Lohmann, G., Werner, M., and Ionita, M.: Links between central Greenland stable isotopes, blocking and extreme climate variability over Europe at decadal to multidecadal time scales, Clim. Dyn., doi:10.1007/s00382-016-3365-3, 2016a.

Rimbu, N., Czymzik, , M., Ionita, M., Lohmann, G., and Brauer, A.: Atmospheric circulation patterns associated with the variability of River Ammer floods: evidence from observed and proxy data, Clim. Past, 12, 377-385, 2016 www.clim-past.net/12/377/2016/doi:10.5194/cp-12377-2016, 2016b.

Scafetta, N., Milani, F., Bianchi, A., Ortolani, V.: On the astronomical origin of the Hallstatt oscillation found in radiocarbon and climate records throughout the Holocene, Earth Sci. Rev., 162, 24-43, 2016.

435 Scherer, S., Crici-Maspoli, M., Schwierz, C., and Appenzeller, C.: Two-dimensional indices of atmospheric blocking and their statistical relationship with winter climate patterns in the EuroAtlantic region, Int. J. Climatol., 26, 233-249, 2006.

Steinhilber, F., Beer, J., and Froehlich, C.:Total solar irradiance during the Holocene, Geophys. Res. Lett., 36, L19704, 2009.

440 Stuiver, M., and Braziunas, T.F.: Atmospheric ${ }^{14} \mathrm{C}$ and century- scale solar oscillations. Nature 338: 405-408, 1989. 
Clim. Past Discuss., https://doi.org/10.5194/cp-2017-137

Manuscript under review for journal Clim. Past

Discussion started: 21 November 2017

(c) Author(s) 2017. CC BY 4.0 License.

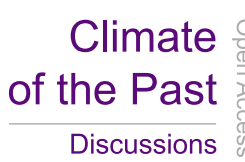

(c) (1)

Swierczynski, T., Brauer, A., Lauterbach, S., Marin-Puertas, C., Dulsky, P., von Grafenstein, U., and Rohr, C.: A 1600 yr seasonally resolved record of decadal-scale flood variability from the Austrian Pre-Alps, Geology, 40, 1047-1050, 2012.

445 Swierczynski, T., Ionita, M., and Pino, D.: Using archives of past floods to estimate future flood hazards, Eos, 98, https://doi.org/10.1029/2017EO066221, 2017.

Toreti, A., Schneuwly-Bollschweiler, M., Stoel, M., and Luterbacher, J.: Atmospheric forcing of debris flows in the southern Swiss Alps, J. Appl. Meteorol. Clim., 52, 1554-1560, doi:10.1175/JAMC-D-13-077.1, 2013.

450 Zängl, G.: Interaction between dynamics and cloud microphysics in orographic precipitation enhancement: a high-resolution modeling study of two North Alpine heavy-precipitation events, Mon. Weather Rev., 135, 2817-2840, 2007.

Wirth, S.B., Glur, L., Gilli, A., and Anselmetti, F.S.: Holocene flood frequency across the Central Alps - solar forcing and evidence for variations in North Atlantic atmospheric 455 circulation, Quat. Sci. Rev. 80, 112-128, 2013. 
Clim. Past Discuss., https://doi.org/10.5194/cp-2017-137

Manuscript under review for journal Clim. Past

Discussion started: 21 November 2017

(c) Author(s) 2017. CC BY 4.0 License.

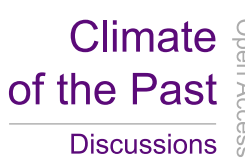

Figure captions

Figure 1. a) The location of the Ammer catchment and b) the time series of daily River Ammer discharge during 1926-2015 and summer (JJA). Units: $\mathrm{m}^{3} / \mathrm{s}$.

Figure 2. Composite maps of daily Z500 (contour) and the corresponding anomalies (color) one day prior (day-1) to River Ammer flood days (discharge $>125 \mathrm{~m}^{3} / \mathrm{s}$ ). Units: $\mathrm{m}$.

Figure 3. a) Composite map of a) daily precipitation and b) maximum daily temperature anomalies one day (day-1) prior to the River Ammer flood days (discharge $>125 \mathrm{~m}^{3} / \mathrm{s}$ ). Units: mm and ${ }^{\circ} \mathrm{C}$.

475 Figure 4. Composite map of total cloudiness anomalies one day prior to River Ammer flood days (discharge $>125 \mathrm{~m}^{3} / \mathrm{s}$ ). Units: $\%$.

Figure 5. a) Frequency of daily River Ammer floods (discharge $>125 \mathrm{~m}^{3} / \mathrm{s}$ ) during the period 1926-2015. Composite map of b) r10mm c) TX90p extreme precipitation and temperature indices for River Ammer flood days during summers. Units: days.

Figure 6. Blocking frequency anomaly pattern associated with River Ammer flood days (discharge $>125 \mathrm{~m}^{3} / \mathrm{s}$ ) during summer. Unit: percentage of blocked days from total number of summer days.

Figure 7. a) Flood layer time series for the period 1851-1999. b) Blocking frequency pattern associated with flood layers in Lake Ammersee sediments during the period 1871-1999. Unit: percentage of blocked days from total number of summer days .

Figure 8. Composite map of station based TX90p indices associated with flood layers for the period 1901-1999. Unit: days.

Figure 9. Composite map of blocking frequency for low solar irradiance summers during 18712010 period. Unit: percentage of blocked days from total number of summer days.

490 Figure 10. a) Time series of flood layer frequency in a 10-yr moving window for the period $3560 \mathrm{BC}$ to $1999 \mathrm{AD}$ b) The $\sim 2.5 \mathrm{kyr}$ cycle reconstructed from the second and third SSA components c) The $\sim 900 \mathrm{r}$ cycle reconstructed from the fourth and fifth SSA components. 
Clim. Past Discuss., https://doi.org/10.5194/cp-2017-137

Manuscript under review for journal Clim. Past

Discussion started: 21 November 2017

(c) Author(s) 2017. CC BY 4.0 License.

\section{Climate of the Past \\ Discussions}

(c) (1)

a)

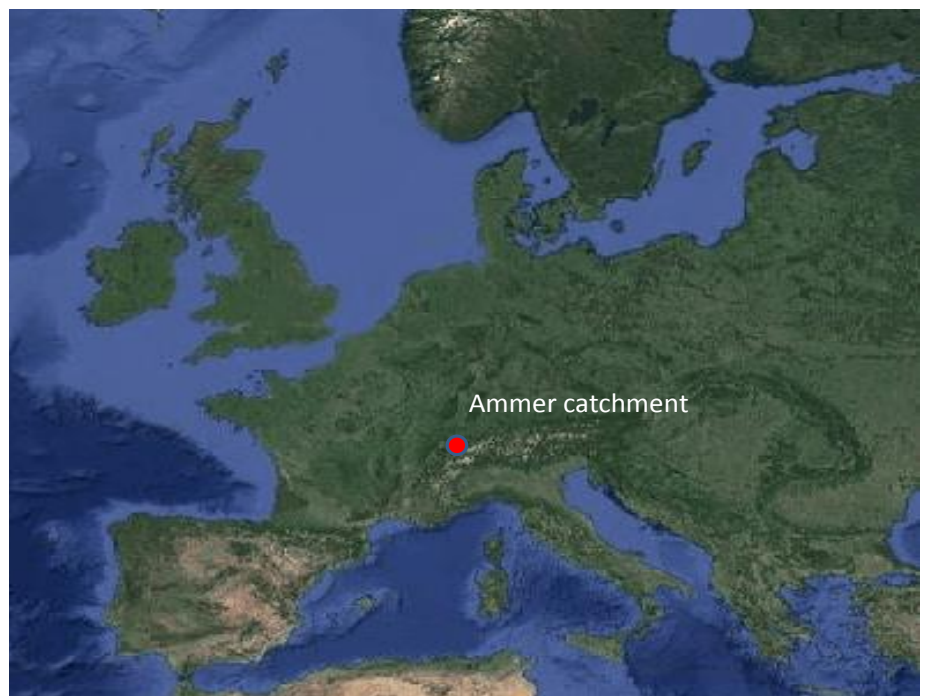

b)

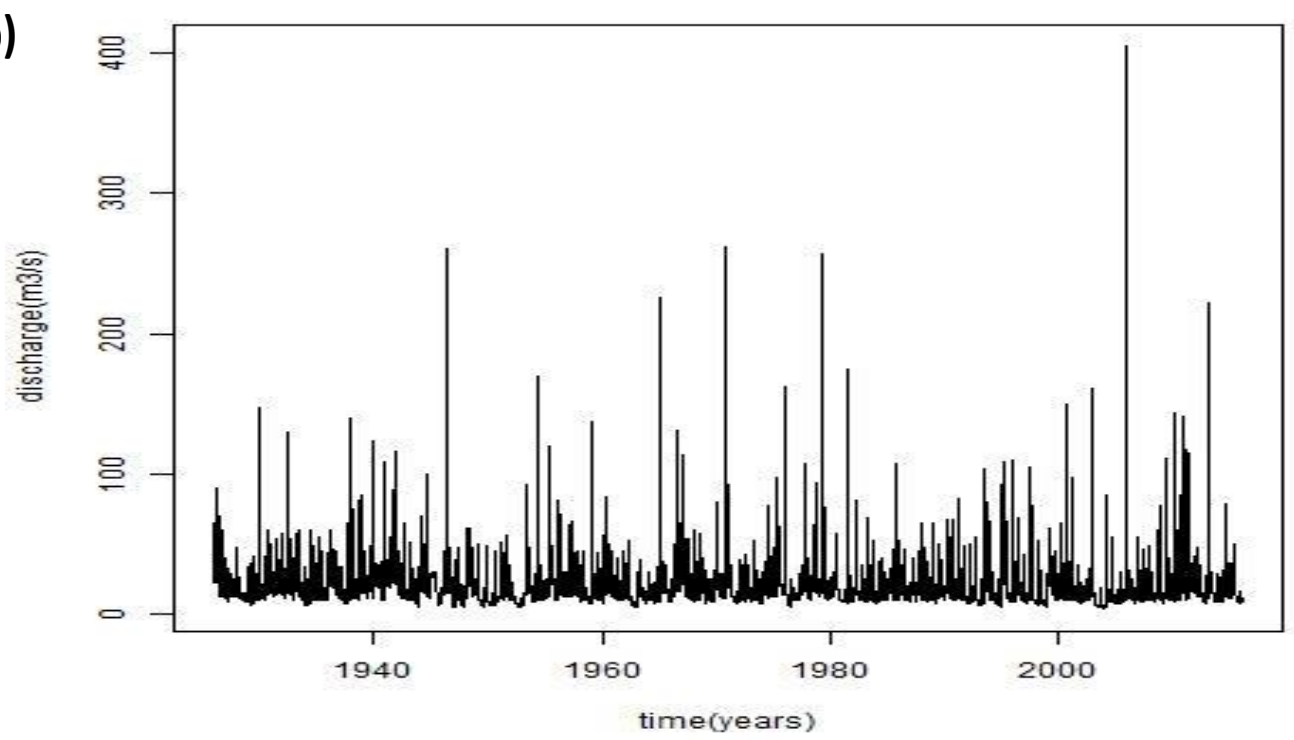

495 Figure 1 a) The location of the Ammer catchment and b) the time series of daily River Ammer discharge during 1926-2015 and summer (JJA). Units: $\mathrm{m}^{3} / \mathrm{s}$. 
Clim. Past Discuss., https://doi.org/10.5194/cp-2017-137

Manuscript under review for journal Clim. Past

Discussion started: 21 November 2017

(c) Author(s) 2017. CC BY 4.0 License.

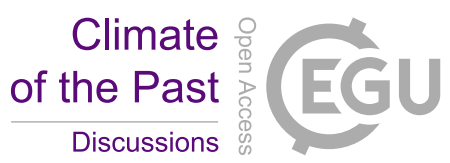

(c) (i)

a)

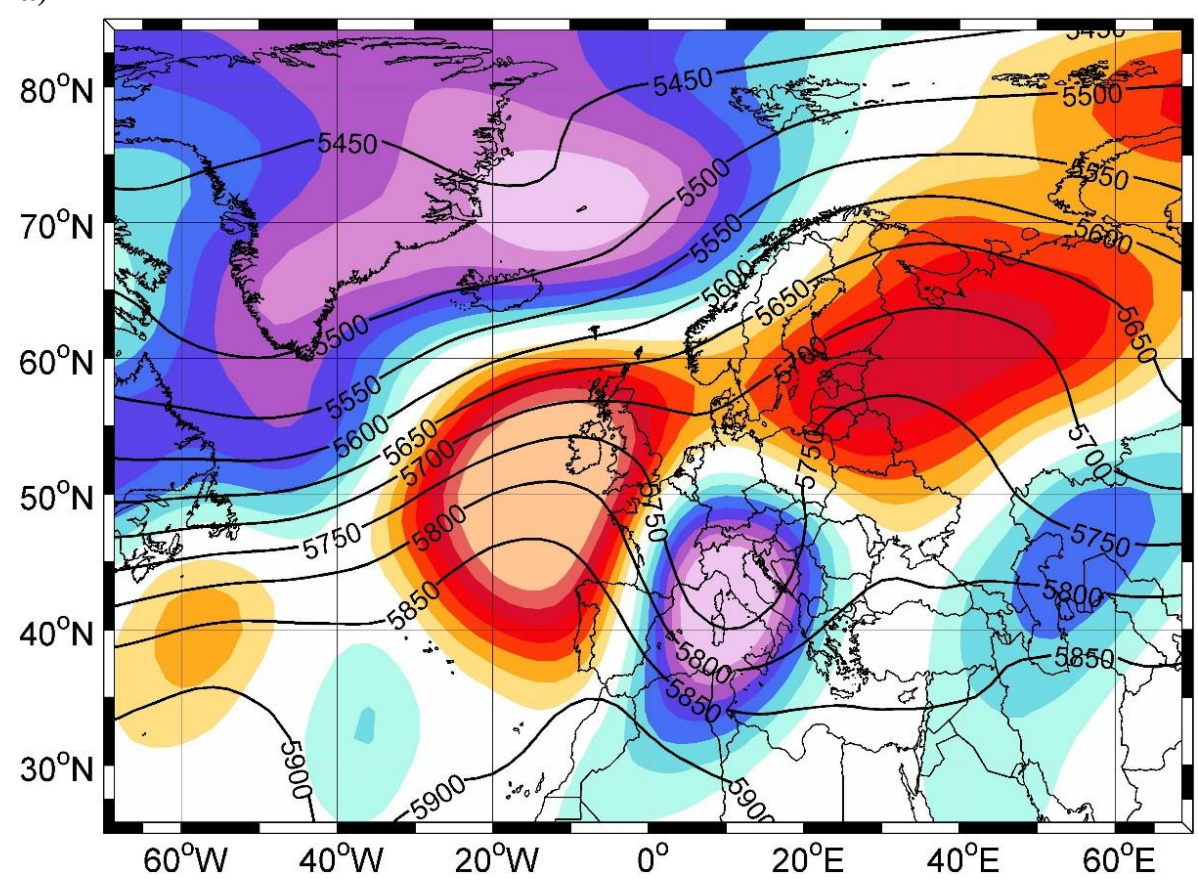

T 80

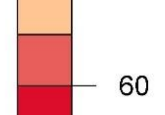

20

$\underline{E}$

Figure 2. Composite maps of daily Z500 (contour) and the corresponding anomalies (color) one day prior (day-1) to River Ammer flood days (discharge $>125 \mathrm{~m}^{3} / \mathrm{s}$ ). Units: $\mathrm{m}$. 
Clim. Past Discuss., https://doi.org/10.5194/cp-2017-137

Manuscript under review for journal Clim. Past

Discussion started: 21 November 2017

(c) Author(s) 2017. CC BY 4.0 License.

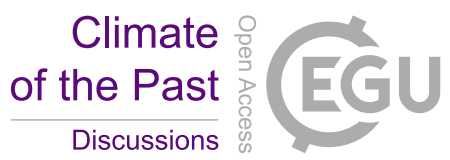

a)

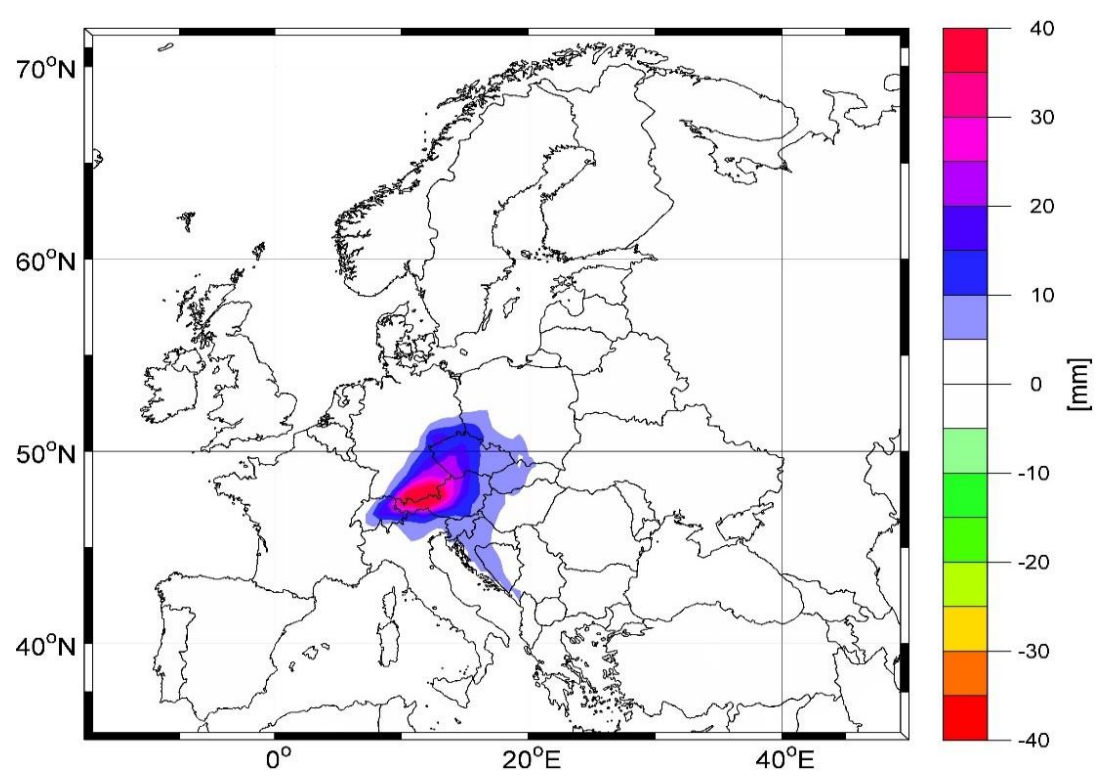

b)

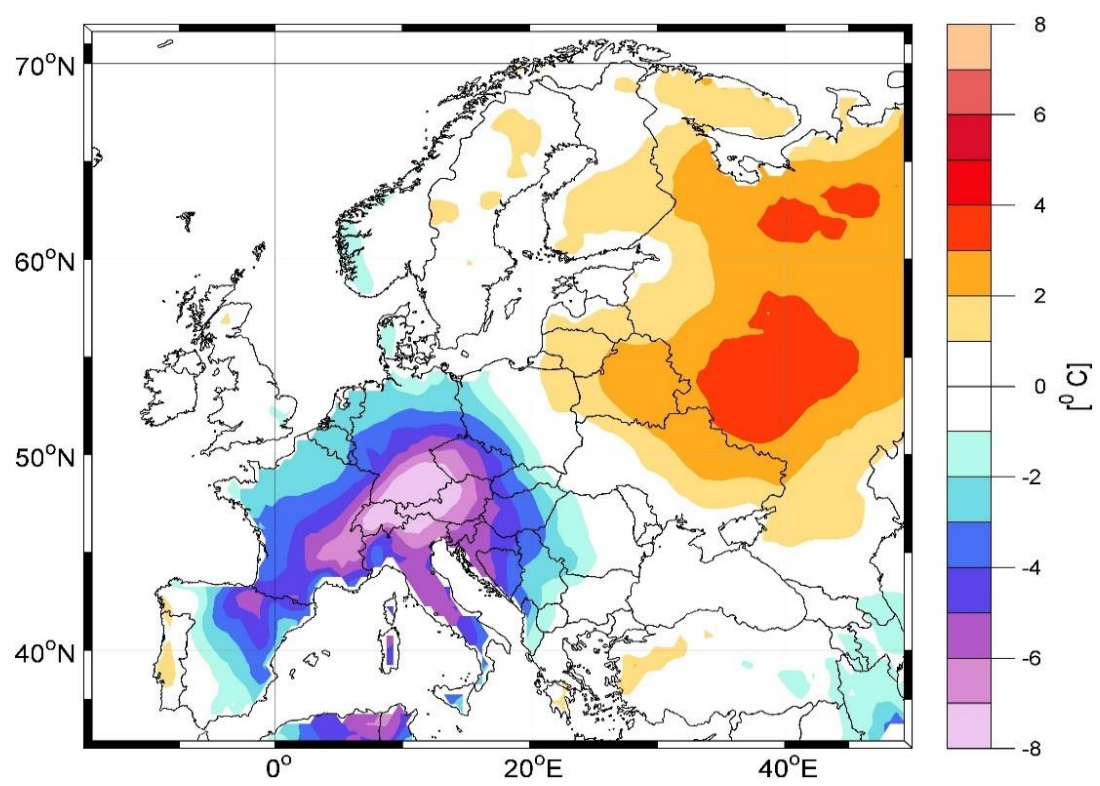

Figure 3 a) Composite map of a) daily precipitation and b) maximum daily temperature anomalies one day (day-1) prior to the River Ammer flood days (discharge $>125 \mathrm{~m}^{3} / \mathrm{s}$ ). Units: $\mathrm{mm}$ and ${ }^{\circ} \mathrm{C}$. 
Clim. Past Discuss., https://doi.org/10.5194/cp-2017-137

Manuscript under review for journal Clim. Past

Discussion started: 21 November 2017

(c) Author(s) 2017. CC BY 4.0 License.

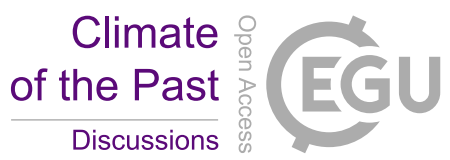

(c) (i)

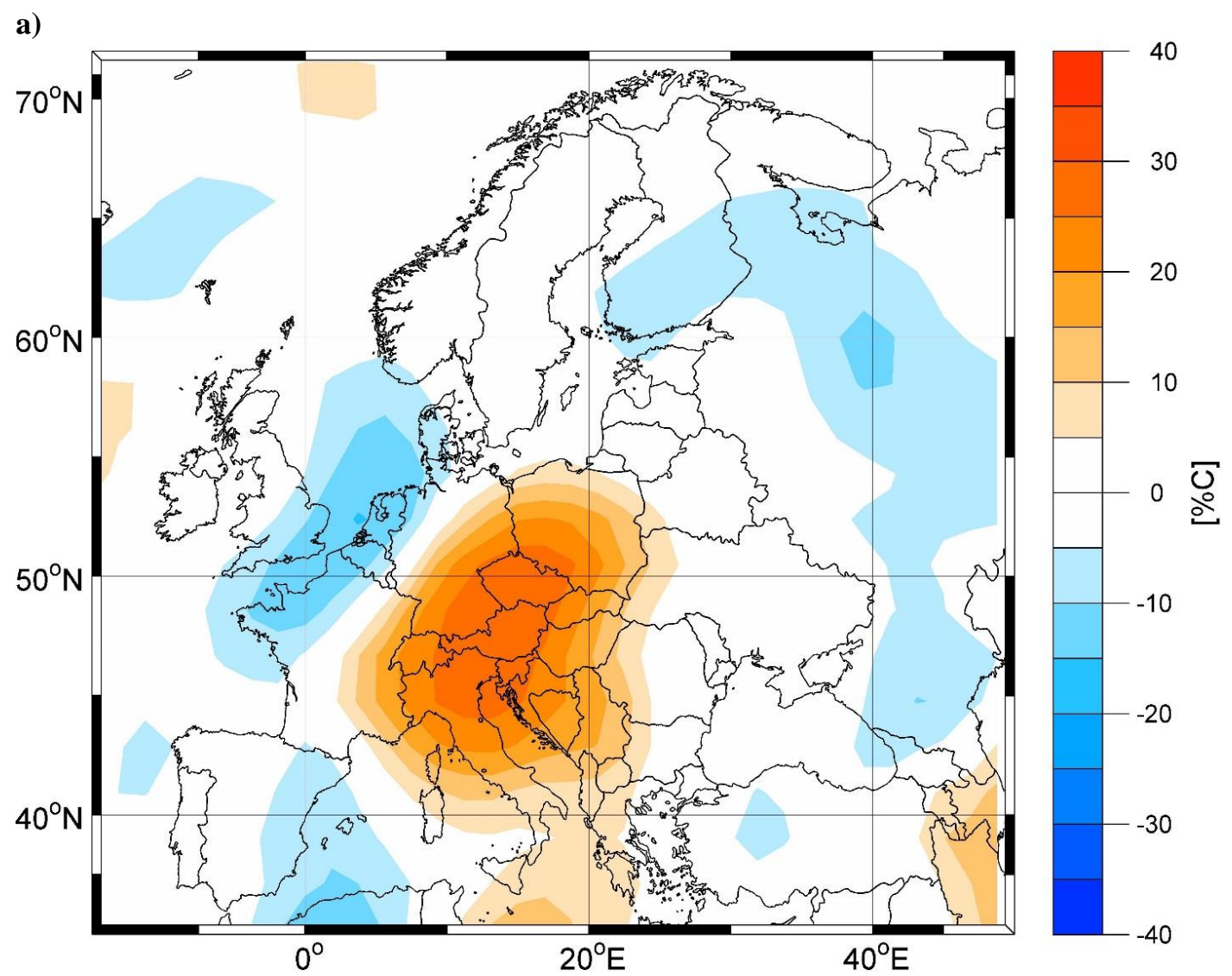

Figure 4. Composite map of total cloudiness anomalies one day prior to River Ammer flood days (discharge $>125 \mathrm{~m}^{3} / \mathrm{s}$ ). Units: $\%$. 
Clim. Past Discuss., https://doi.org/10.5194/cp-2017-137

Manuscript under review for journal Clim. Past

Discussion started: 21 November 2017

(c) Author(s) 2017. CC BY 4.0 License.

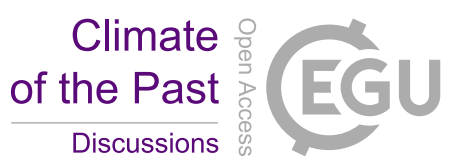

(c) (i)

a)

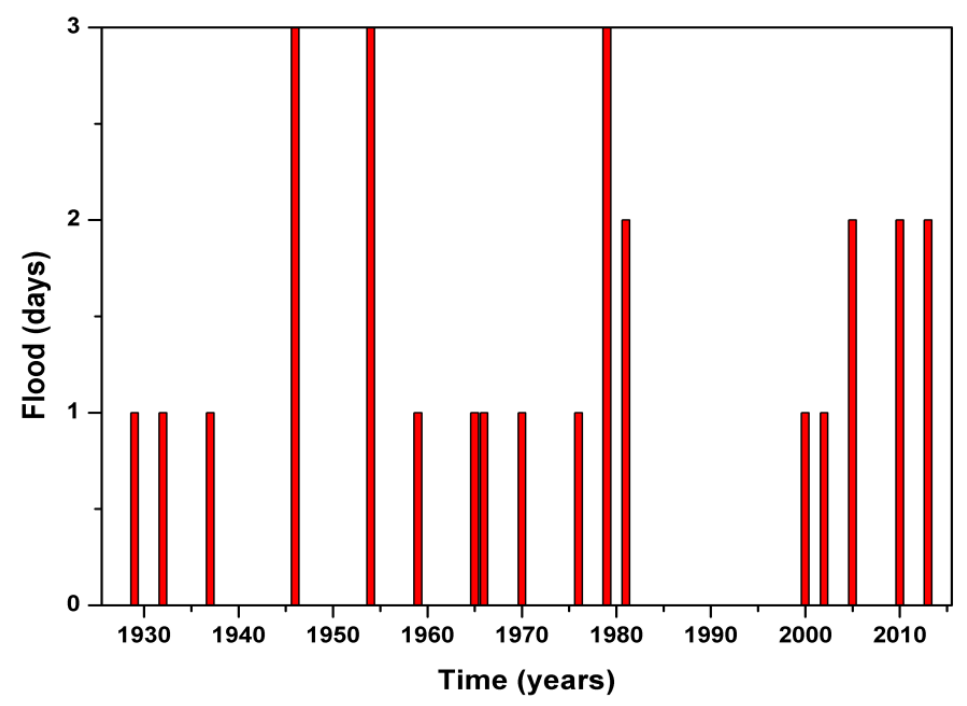

b)

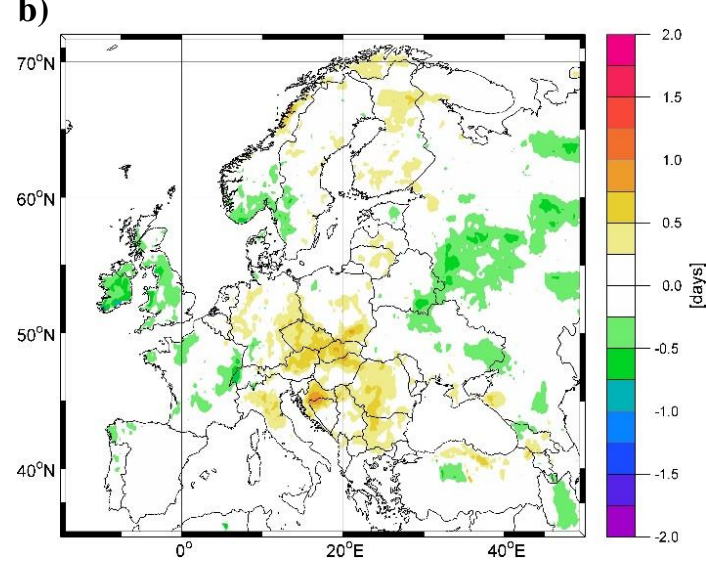

c)

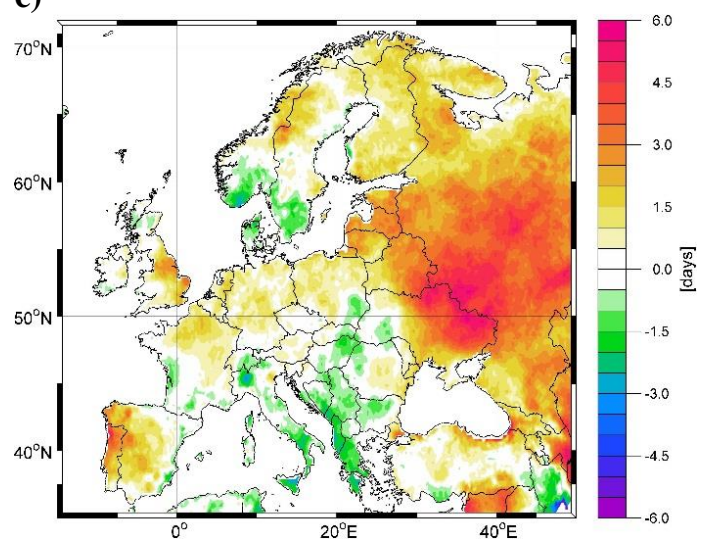

Figure 5. a) Frequency of daily River Ammer floods (discharge $>125 \mathrm{~m}^{3} / \mathrm{s}$ ) during the period 1926-2015. Composite map of b) r10mm c) TX90p extreme precipitation and temperature indices for River Ammer flood days during summers. Units: days. 
Clim. Past Discuss., https://doi.org/10.5194/cp-2017-137

Manuscript under review for journal Clim. Past

Discussion started: 21 November 2017

(c) Author(s) 2017. CC BY 4.0 License.

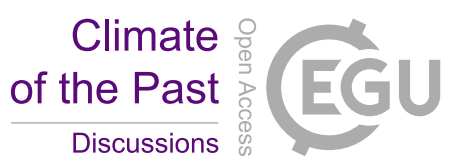

(c) (i)

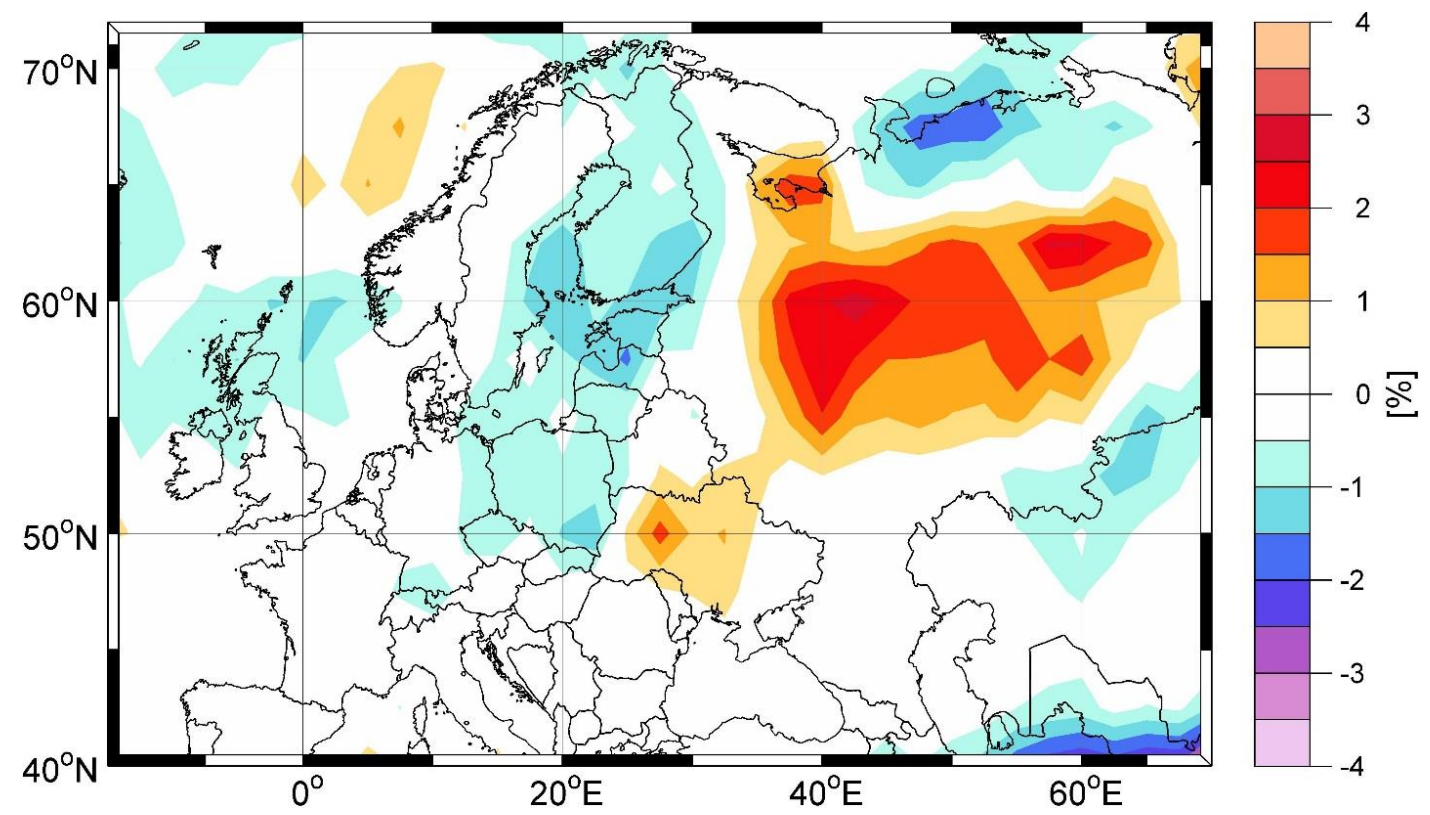

Figure 6. Blocking frequency anomaly pattern associated with River Ammer flood days (discharge $>125 \mathrm{~m}^{3} / \mathrm{s}$ ) during summer. Unit: percentage of blocked days from total number of summer days. 
Clim. Past Discuss., https://doi.org/10.5194/cp-2017-137

Manuscript under review for journal Clim. Past

Discussion started: 21 November 2017

(c) Author(s) 2017. CC BY 4.0 License.

a)

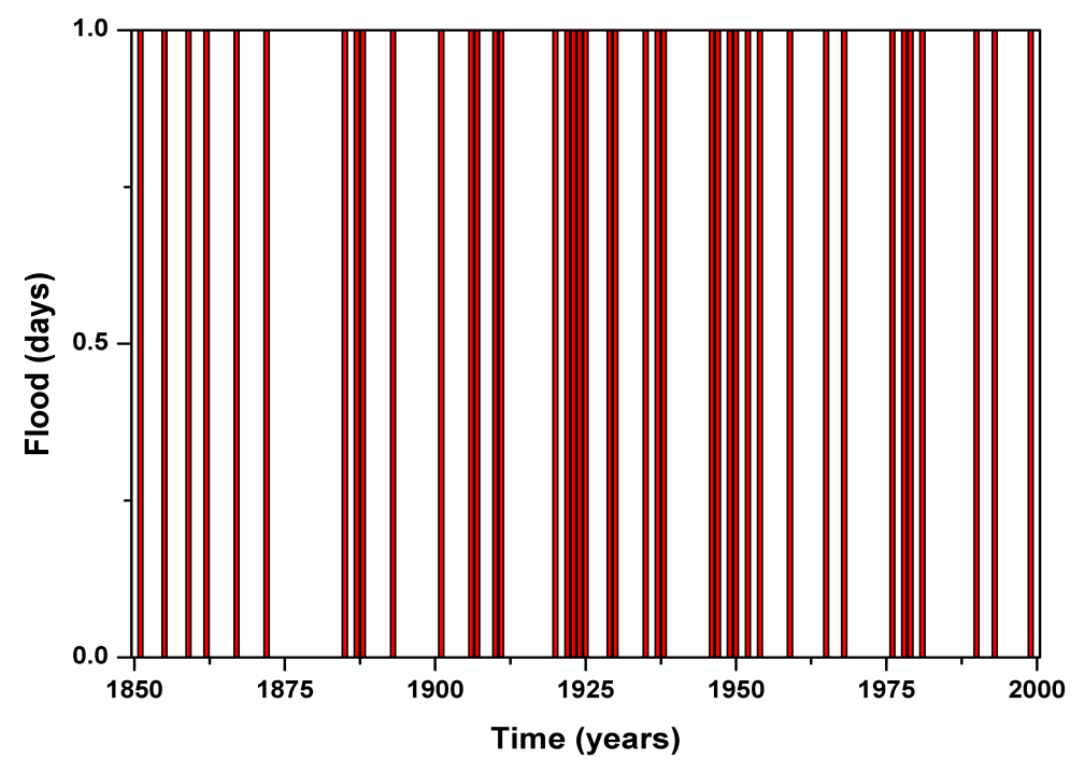

b)

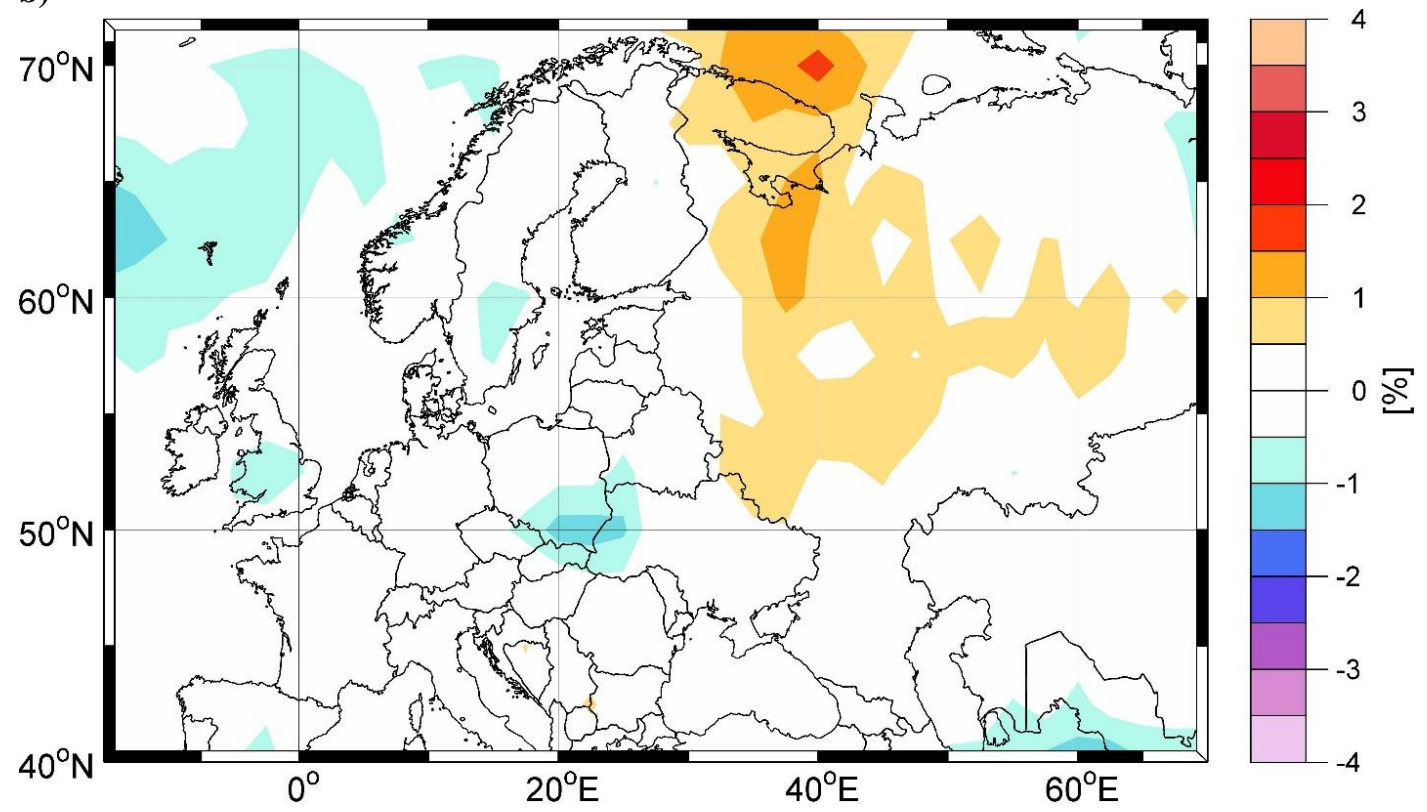

Figure 7. a) Flood layer time series for the period 1871-1999. b) Blocking frequency pattern associated with flood layers in Lake Ammersee sediments during the period 1871-1999. Unit: percentage of blocked days from total number of summer days . 
Clim. Past Discuss., https://doi.org/10.5194/cp-2017-137

Manuscript under review for journal Clim. Past

Discussion started: 21 November 2017

(c) Author(s) 2017. CC BY 4.0 License.

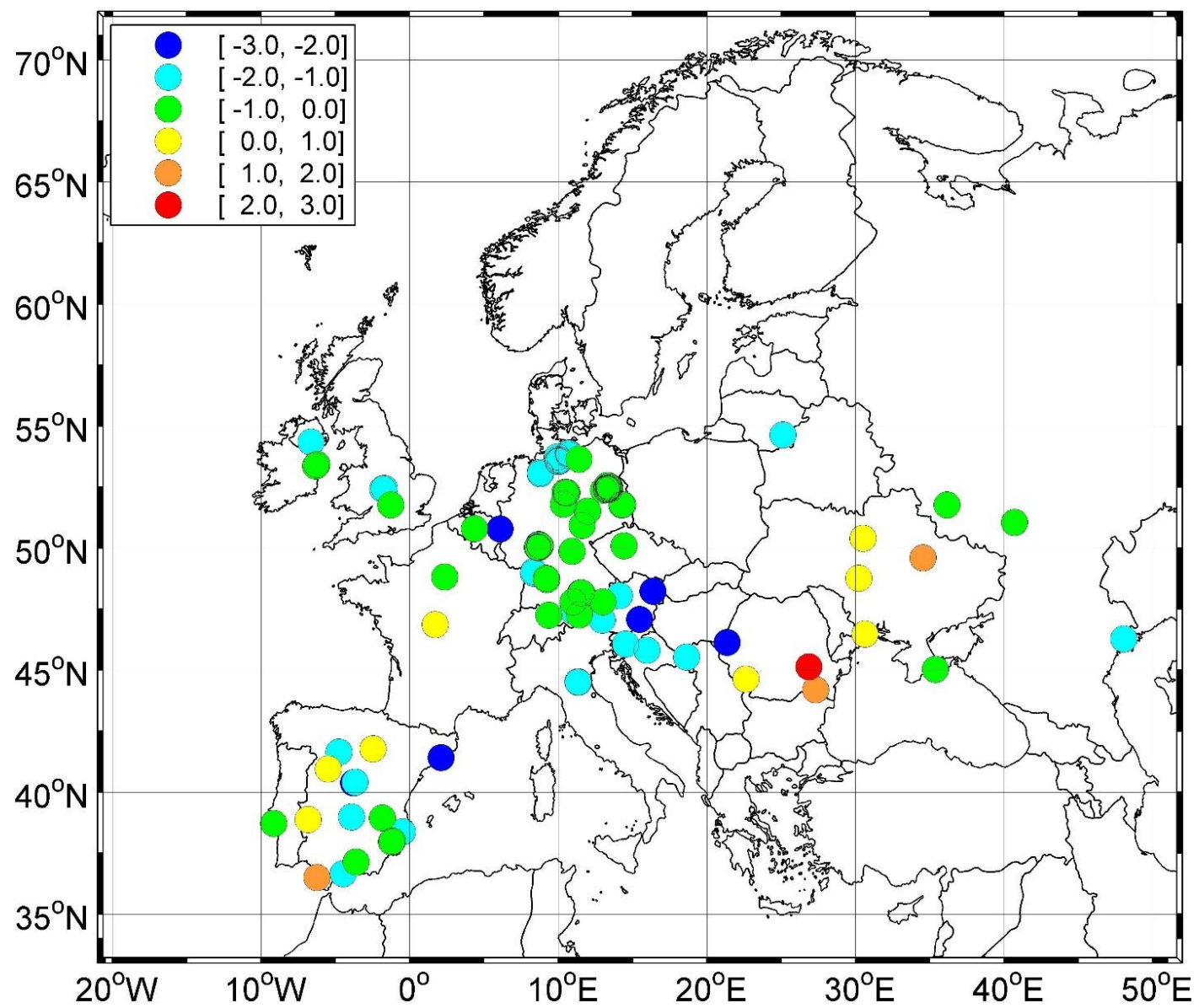

Figure 8. Composite map of station based TX90p indices associated with flood layers for the period 1901-1999. Units: days. 
Clim. Past Discuss., https://doi.org/10.5194/cp-2017-137

Manuscript under review for journal Clim. Past

Discussion started: 21 November 2017

(c) Author(s) 2017. CC BY 4.0 License.

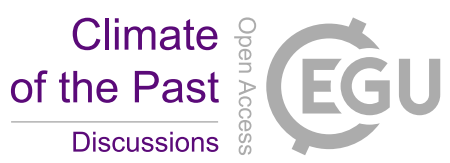

(c) (i)

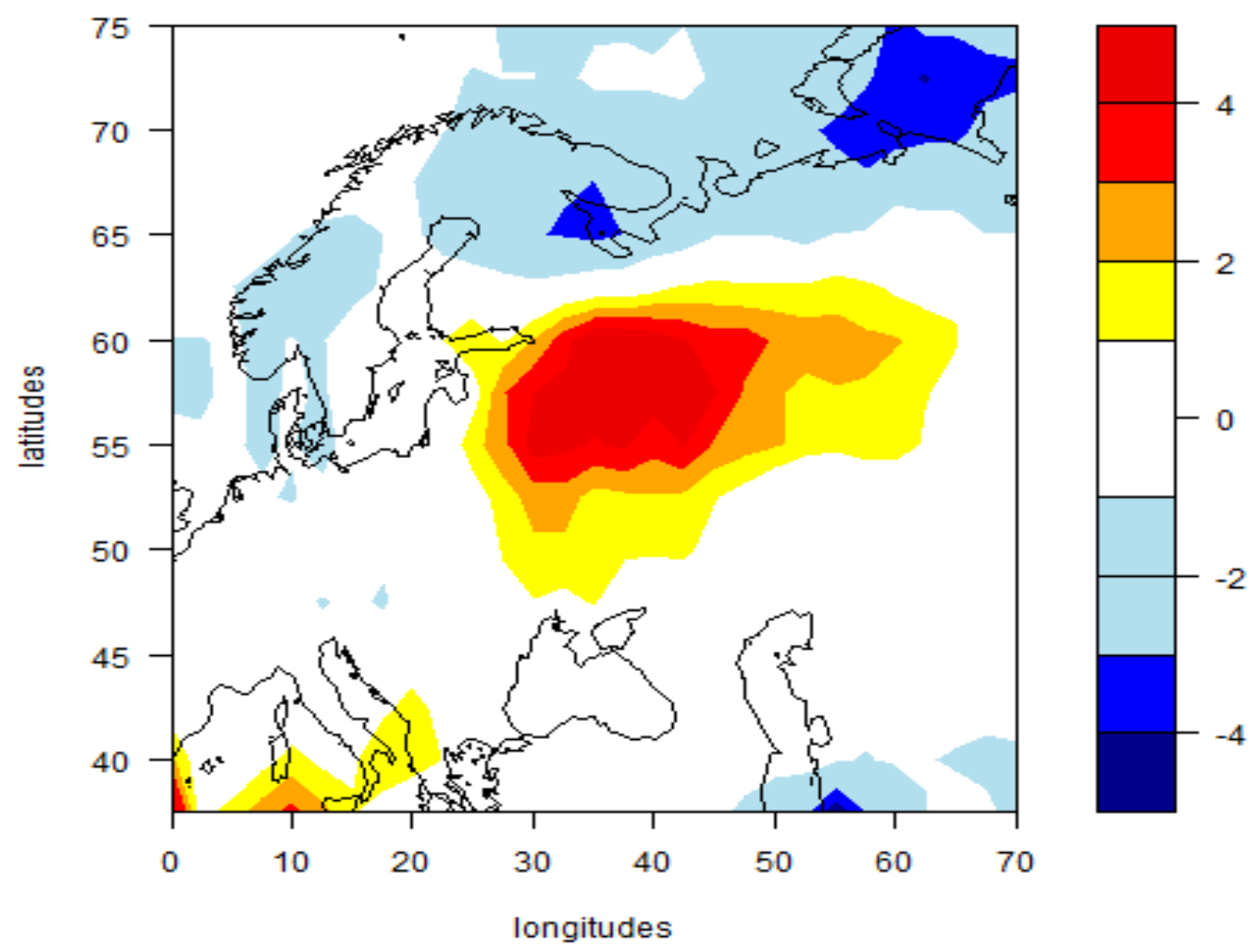

Figure 9. Composite map of blocking frequency for low solar irradiance summers during 18712010 period. Units: percentage of blocked days from total number of summer days. 
Clim. Past Discuss., https://doi.org/10.5194/cp-2017-137

Manuscript under review for journal Clim. Past

Discussion started: 21 November 2017

(c) Author(s) 2017. CC BY 4.0 License.

a)

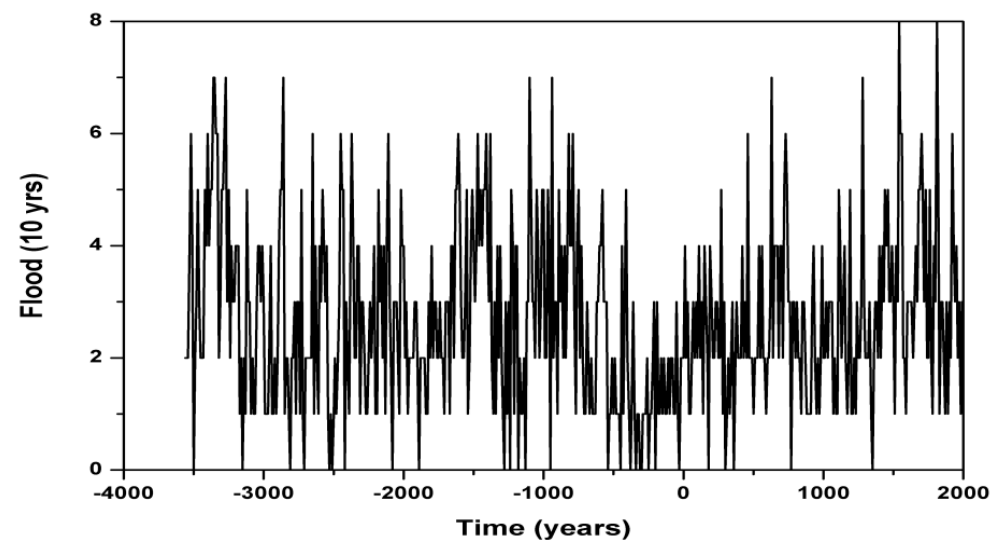

b)

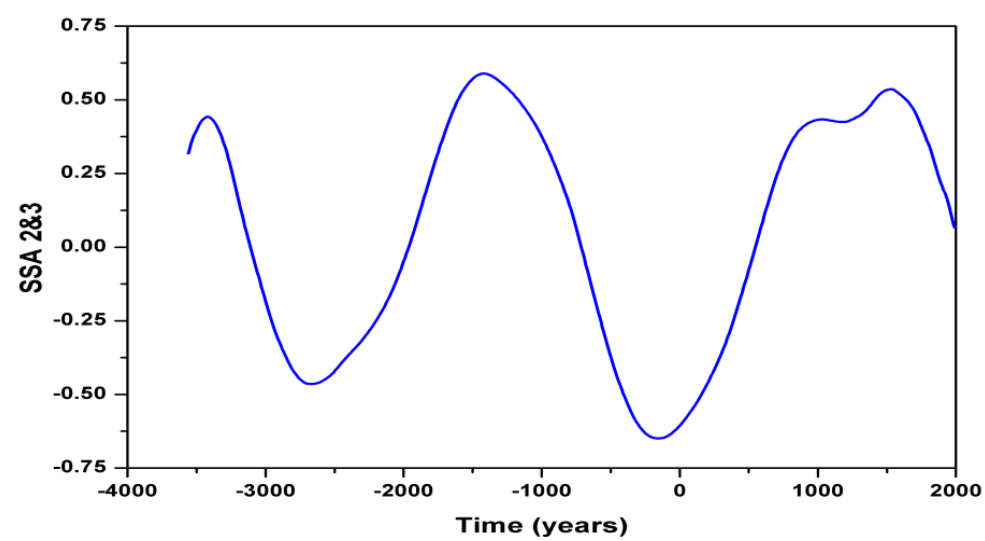

c)

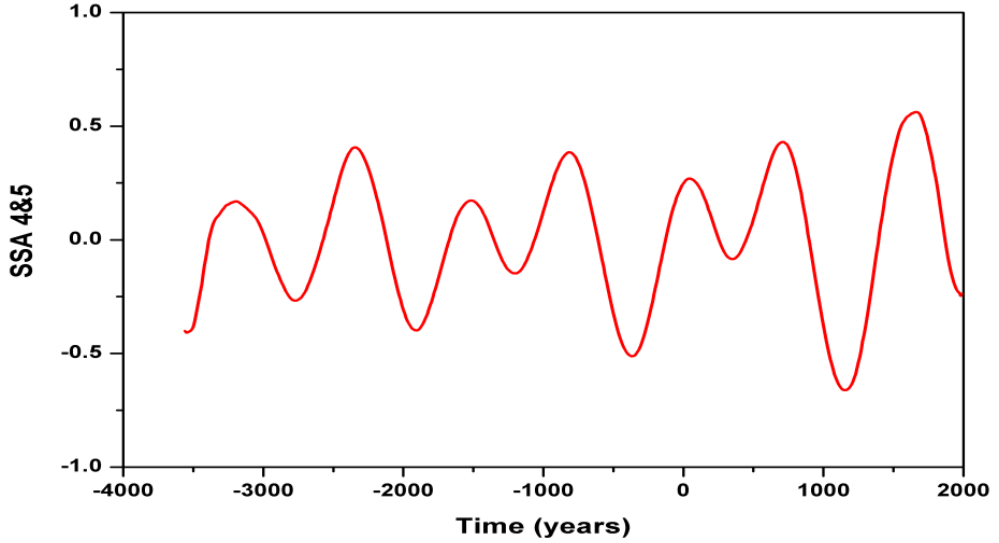

Figure 10. a) Time series of flood layer frequency in a 10-yr moving window for the period $3560 \mathrm{BC}$ to $1999 \mathrm{AD}$ b) The $\sim 2.5 \mathrm{kyr}$ cycle reconstructed from the second and third SSA components c) The $\sim 900 \mathrm{r}$ cycle reconstructed from the fourth and fifth SSA components. 